\title{
Return migration and economic outcomes in the conflict context
}

\author{
Sonja Fransen \\ University of Amsterdam \\ Isabel Ruiz \\ University of Oxford \\ Carlos Vargas-Silva (contact author) \\ University of Oxford \\ 58 Banbury Road \\ Oxford, OX2 6QS \\ United Kingdom \\ carlos.vargas-silva@compas.ox.ac.uk \\ Phone: +4401865284975
}

\section{Acknowledgements}

The authors thank Pascal Achard, Brian Dillon, Taryn Dinkelman, Craig Loschmann, Edouard Mensah, Juan Carlos Muñoz-Mora, Susan Pozo, Mathis Wagner and participants at seminars at the Centre on Migration, Policy and Society (COMPAS), Institute for the Study of Labor (IZA), Kasetsart University, International Migration Institute (IMI), Refugee Studies Centre (RSC), European University Institute and World Bank for helpful comments and suggestions. We are also thankful to the editor and two anonymous referees for comments and suggestions.

\section{Funding}

This work was supported by the UK Department of International Development (DFID) and the Institute for the Study of Labour (IZA) Growth and Labour Markets in Low Income Countries Programme (GLM | LIC). The views expressed in this document are not necessarily those of DFID, IZA or GLM | LIC. 


\begin{abstract}
Knowledge about the economic implications of refugee return is essential in order to develop adequate policies in the post-conflict period. In this paper we explore differences in economic outcomes between return migrant households and non-migrant households using panel data from Burundi, a country which experienced large scale conflict-led emigration and massive post-war refugee return. We use proximity to the border for identification purposes. The results indicate that returnee households have significantly lower levels of livestock, which is the main form of capital accumulation in Burundi. Returnee households also report lower values of subjective economic well-being relative to other households. The gap between returnee and non-migrant households is driven by more recent returnees, defined as those that returned less than ten years ago. Our search for channels suggests that returnees are more likely to engage in economic activities that are generally correlated with lower levels of livestock. One possible explanation for this dynamic relates to the legal restrictions on economic activities faced by returnees while in displacement, which resulted in high levels of inactivity abroad and a potential loss/deterioration of skills.
\end{abstract}

JEL Codes: F22, E24, D74

Keywords: Return migration, refugees, labor markets 


\section{Return migration and economic outcomes in the conflict context}

\section{Introduction}

International migration is often temporary, and evidence suggests that, due to skills acquired abroad, many migrants return home to take advantage of a higher return in their home country (Dustmann et al., 2011; Dustmann and Görlach, 2016; Reinhold and Thom, 2013; Wahba, 2015a). Examples of these skills include knowledge of a new language, different markets and production techniques. There is substantial statistical evidence that international migration experiences often result in a wage premium upon returning home (Co et al., 2000; Barrett and Goggin, 2010; Reinhold and Thom, 2013; Wahba, 2015b). Several studies also have found that migrants accumulate resources for later investments in the home country (Yang, 2006), and returnees are particularly likely to become entrepreneurs upon return (Dustman and Kirchkamp, 2002; Mesnard, 2004; McCormick and Wahba, 2001; Piracha and Vadean, 2010).

The previous literature on return migration has focused on the case of "voluntary" migrants. However, millions of individuals around the world have been forced to leave their home countries in order to escape violence. The United Nations High Commission for Refugees (UNHCR) estimates that there were 21 million international refugees worldwide in 2015, and more than $80 \%$ of them are in neighboring developing countries (UNHCR, 2016). Many of these refugees eventually go home and become "return migrants." In this paper, we explore the economic implications of being a returnee in a situation in which conflict was the original driver of a large-scale migration, followed by massive return migration after the end of the conflict.

International migration and return in a conflict/post-conflict context could perhaps also lead to potential skills and labor market experience gains for the migrants. Refugees, including those in camps, are often involved in trading relationships with host communities and participate 
in host labor markets. For instance, the trade in milk and meat between Somali refugee camps and neighboring communities in Kenya was estimated to be USD 3 million in 2010 (Enghoff et al., 2010). In Tanzania, the presence of refugees from Burundi and Rwanda initially led to a "huge upsurge in business and trade conducted by both hosts and refugees" (Whitaker, 2002). Products that were previously exported to Burundi and Rwanda were now traded in refugee camps inside Tanzania, and in many cases, refugees used food aid to trade with host communities. Refugees also participate in host labor markets, and in some cases, even displaced the local workers (Ruiz and Vargas-Silva, 2015; 2016).

However, the decision to migrate, the experiences abroad and the decision to return are different in a conflict context and therefore so might be the consequences of being a returnee. In these situations, migration might take place even if the expected earnings gap between the host and home country is small or even negative. Although economic considerations are relevant, the level of violence often escalates abruptly during crises, making security the main determinant of migration. In addition, those escaping conflict usually have limited transportation options and often must walk to their destinations (Durieux, 2008), a fact that limits the available destinations and the possibility of making significant economic gains from migration. Moreover, in a conflict context, households often leave behind livestock, land and other assets that are difficult to reclaim in the post-conflict period (Ruiz and Vargas-Silva, 2013).

Sometimes the host country also imposes restrictions on the movements and economic activities of refugees (Zetter and Ruaudel, 2016). For instance, Ongpin (2008) explains that a few years after the arrival of the refugees, Tanzania introduced restrictive legislation that prohibited refugees from possessing farms or owning land within the camps and from seeking employment outside the camps. This resulted in high levels of inactivity and made refugees 
highly dependent on humanitarian aid (UNHCR, 2009; Harild et al., 2015). Other factors may also lead to high levels of inactivity of forced migrants. For instance, Lehrer (2010) explains that a "culture of idleness" developed over time in displacement camps in Northern Uganda, resulting in high levels of inactivity for different groups, particularly men.

The decision to return is also likely to be affected by different factors in a conflict/post conflict context. A decrease in the level of violence back home can be a key determinant of the timing of voluntary returns. However, return is often involuntary, including cases of forced repatriation in which the host country considers that international protection is no longer justified and declares refugees to be illegal residents (Black and Koser, 1999). A case of involuntary return contrasts greatly with a case in which returnees are able to decide the timing of their return and take advantage of differences in the reward to particular skills between the two countries.

Given the particular dynamics of the migratory experience of the displaced, the implications and consequences of their migration should be explored in detail. In order to develop adequate policies in the post-conflict period, knowledge about the implications of being a returnee in this context is essential. The purpose of this paper is to increase the knowledge base on this topic. For the empirical analysis, we use longitudinal data from Burundi, a country that experienced a major civil conflict between 1993 and 2000. A returnee is defined as someone who crossed an international border for security or political reasons, spent at least three months abroad and later returned home. We use the survey data to test differences in livestock levels between returnees and stayees. As noted by Bundervoet (2009), livestock in Burundi is the main form of capital accumulation and acts as a savings and insurance mechanism. Finally, we explore the role of economic activities (during and after migration), vulnerability to crime and health 
shocks, time since return, and time spent abroad as potential key factors to explain the differences between returnees and stayees.

A large share of Burundi's population was displaced to other countries during the conflict, with neighboring Tanzania being the main destination of migrants. In fact, at the time, the Burundian refugee population was the second largest refugee population worldwide, only behind Afghan refugees (Vorrath, 2008). After several years, Tanzania closed all refugee camps, stopped providing legal protection to the refugees, and repatriated the remaining camp residents to Burundi (European Commission, 2009; Harilds et al., 2015). The large majority of Burundian refugees from the 1993-2000 conflict have now returned to the country, making it possible to explore the medium-term implications of their international migration experiences. We use countrywide longitudinal data that was collected in 2011 and 2015. The survey has detailed information about livestock and economic activities of returnees and stayees. We also have information on returnees' economic activities just before and during migration.

In addition, we explore whether the dynamics have changed across rounds of the survey. Any negative or positive gaps between returnee and stayee households may have possibly disappeared or increased over time. For instance, Verwimp and Muñoz-Mora (2013) estimate that it took 8 to 10 years after return for the level of welfare of Burundi's internally displaced households to converge to that of the non-displaced households. O'Reilly (2015) finds that in Northern Uganda, returnee households experienced a growth rate of per capita consumption that was significantly higher than comparable non-returnee households.

We control for the level of violence exposure during the conflict period and other key factors in the estimations. However, unobserved factors may have possibly affected the initial likelihood of becoming an international migrant (and therefore a returnee). We use several 
techniques to address this possibility. First, we use geographical factors, such as proximity to the border of Tanzania, as an instrument in our estimations. In the case of Burundi, most displacement took place by foot, and distance to Tanzania was one of the key determinants of being an international migrant. Second, as a robustness check, we use propensity score matching to compare outcomes of returnee and stayee households.

Our results show that, compared to stayees, returnee households have significantly lower levels of livestock. Returnees are more likely to engage in agricultural activities for subsistence or as employees, both of which are activities associated with lower levels of livestock. The evidence also suggests that legal and practical restrictions on economic activities in Tanzania could have resulted in high levels of inactivity while in displacement, a factor associated with a deterioration/loss of skills. This factor may also explain the economic gap between returnee and stayee households. Finally, the gap between returnee and stayee households decreased with the length of time since return.

\section{Conflict and forced displacement in Burundi}

Burundi is a landlocked country in the Great Lakes region of Africa. It is a relatively small country (27,830 square kilometers) and has consistently ranked as one of the poorest countries in the world. In 2014, the country occupied the 184th place (out of 188) in the Human Development Index (United Nations Development Programme, 2015). Also in 2014, the gross national income per capita was only USD 270, well below the average for sub-Saharan Africa (USD 1,699). The country is densely populated, and while close to $90 \%$ of the population depends on subsistence agriculture, cultivable land is relatively scarce (World Bank, 2015).

The country is divided along ethnic lines between Hutus and Tutsis. Hutus represent the majority of the population (approximately 85\%), but Tutsis have historically maintained control 
of the key government positions (Krueger and Krueger, 2007). The first democratic elections of Burundi were held in 1993. The winner of the election, Melchior Ndadaye, was the first Hutu president of the country. Ndadaye was assassinated a few months after the election. This assassination and the political events that followed led to a long civil war in which an estimated 300,000 people were killed (Ngaruko and Nkurunziza, 2000). ${ }^{1}$

Hundreds of thousands of people fled their homes in search of refuge during the conflict period. In this study, we are interested in those who left the country, most of whom were international refugees in neighboring countries. As shown in Figure 1, Burundi shares borders with the Democratic Republic of Congo (DRC, 236 kilometers), Rwanda (315 kilometers) and Tanzania (586 kilometers). In these neighboring countries, Tanzania has been historically perceived as the stable "safe haven" for refugees (Kamanga, 2005). In the early 1990s, while the DRC and Rwanda were also immersed in conflict (Ongpin, 2008), unsurprisingly, the Burundian conflict resulted in a large-scale forced displacement to Tanzania (Ruiz et al., 2015). Official estimates from UNHCR suggest that, at the peak of the refugee crisis, there were nearly half a million registered Burundian refugees in Tanzania (UNHCR, 2008).

\section{[Figure 1]}

Figure 2 reports the UNHCR estimates of the number of Burundian refugees in Tanzania in the mid-2000s, per province of origin in Burundi (in brackets). The second number in each province is the number of refugees from that province, as a share of the entire population of the province that was recorded in the 1990 Census (in parenthesis). As evidenced by Figure 2, most

\footnotetext{
${ }^{1}$ There are several sources for understanding the origins and development of the conflict and war in Burundi. Of particular interest was the escalation of conflict leading to "untargeted and random attacks" to the overall population. Refer to Bundervoet (2009), Bundervoet et al. (2009), Krueger and Krueger (2007), Uvin (1999) and Voors et al. (2012) for more information.
} 
of the refugees came from provinces that border Tanzania. This is expected, as most of the refugee migration took place by foot.

[Figure 2]

Burundian refugees in Tanzania were placed in refugee camps in the northwestern part of the country (Maystadt and Verwimp, 2014). Unlike the previous cohorts, such as the 1972 refugees, Burundian refugees fleeing to Tanzania from 1993 onwards were not given land for agricultural activities (Harild et al., 2015). Still, shortly after arrival, many did engage in casual agricultural employment in neighboring villages (Ruiz and Vargas-Silva, 2016). Whitaker (2002) explains that in some areas close to the camps, the wage rate for casual work initially decreased by $50 \%$. However, over time, the Tanzanian government restricted the movement of refugees to four kilometers from the camps and imposed limitations on the types of economic activities in which refugees could engage (Millner, 2013). Refugees could not legally work outside of camps or own farms in the camp areas. As a result, many of these refugees were fully dependent on international aid support for the entire duration of their stay in Tanzania (Harild et al., 2015).

The dependence of refugees on aid and restrictions on work could have had long-term consequences. There is substantial evidence which suggests that inactivity often leads to a deterioration of skills, discouragement and poorer labor market outcomes (Chin, 2005; Hainmueller et al., 2016). Collier and Duponchel (2012) used the term "forgetting by not doing' in reference to the skills atrophy that affect many firms in conflict affected areas. A similar type of phenomenon could have affected inactive Burundian refugees in Tanzania.

The Arusha Peace and Reconciliation Agreement was signed in 2000, putting an official end to the conflict. Around that period Tanzania put pressure to close refugee camps and required the return of refugees to Burundi. As shown in Figure 3, approximately 560,000 
refugees returned to Burundi from Tanzania during the period of 2001-2013. This number includes children of Burundian refugees who were born in Tanzania (Fransen, 2015). The peaks in 2008 and 2012 respond to the closing of large refugee camps by Tanzanian authorities in these years.

[Figure 3]

Reports suggest that most returnees went back to their communities of origin (Kirchhof, 2009). The Arusha peace agreement highlighted concerns regarding land access for returnees and instructed the repossession of land for returnees or, failing that, adequate compensation for the value of the land. In practice, the massive return to Tanzania led to an increase in disputes over land and many returnees have not been properly compensated for their land (Fransen and Kuschminder, 2012). The lack of access to land can exacerbate differences between returnees and stayees.

In 2015, over 200,000 people were displaced from Burundi to neighboring countries, with over 100,000 going to Tanzania (UNHCR, 2015a, 2015b). This is the first episode of large forced displacement in the country in over a decade. The displacement was the result of increasing tensions and violence in response to the April 2015 announcement that the President was running for a third term in office. Many interpreted a third term in office as a violation of the Arusha peace agreements. The second round of data collection for this paper was finalized approximately six weeks before the President's announcement and before this new wave of displacement, as discussed in more detail below.

\section{Methodology}

\subsection{Data}


The data collection for this study took place between January and early March of 2011 and 2015 in all 17 provinces of Burundi. The authors worked with a local research company to collect the data. For the 2011 survey, the primary sampling unit was the colline. One hundred collines were selected. These collines were distributed over the provinces of Burundi according to the demographic weight of each province in the 2008 Burundi Census. Within each colline, a souscolline was randomly chosen. Finally, within each selected sous-colline, 15 interviews were conducted with randomly selected households (total 1,500 households) and one community representative. The 2015 survey followed-up with the same households, and when possible, community leaders. Figure 4 shows the distribution of the communities across Burundi. The number of households interviewed by province ranged from 45 to 135 .

[Figure 4]

In this study, we use the community, household and individual components of the survey. We exclude households from Bujumbura, the capital of Burundi, from the analysis. Due to logistical difficulties the survey included two cross-sections of households in Bujumbura (i.e. different households in each round), while in the rest of the country the same households were interviewed in 2011 and 2015. It is common for studies about conflict and displacement in Burundi to exclude Bujumbura. This is because the conflict and displacement dynamics were markedly different (e.g. Fransen, 2015; Verwimp and Van Bavel, 2014). The re-interview rate of households outside Bujumbura was over $90 \%$. After excluding households in Bujumbura, we are left with a total of 904 households living in 87 communities for which we have complete data in 2011 and 2015.

Appendix 1 includes the definition and source of all the variables included in the estimations. We start the analysis by looking at the implications of household returnee status on 
livestock levels. In order to standardize the livestock across individuals, we use Tropical Livestock Units (TLUs). TLUs allow animal species of different average size to be compared by a common unit. This measure is based on the typical weight of the animal raised to the power of 0.75 (also known as the metabolic body weight), compared with the equivalent figure for an animal of $250 \mathrm{~kg}$. Please to note that this measure relies on both species being under the same feeding system (which is a reasonable assumption in our case), but does not account for the possibility of different breeds of the same species.

Following Bundervoet (2009, 2010), who conducted an exploration of the impact of conflict on livestock in Burundi, we use the following units as weights: 1 cow/ox $=1$ TLU, 1 sheep $=0.17 \mathrm{TLU}, 1$ goat $=0.17 \mathrm{TLU}, 1 \mathrm{pig}=0.25 \mathrm{TLU}$ and 1 fowl $=0.01 \mathrm{TLU}^{2}{ }^{2}$ These units mean, for instance, that four pigs will roughly consume as much as one cow. After standardizing the livestock in TLUs, we divide the standardized value by the number of adult members of the household. As such, our dependent variable is livestock in TLUs per adult household member, defined as those who are 14 years of age or older.

Table 1 reports the mean value of livestock for stayee and returnee households. In the table, returnee households are defined as households with at least one member who is a returnee. In the regressions below, we also show results with alternative definitions of a returnee household. Returnee households have a lower average livestock than stayee households. The gap is equal to 0.06 TLUs per adult member in 2011 and 0.08 TLUs per adult member in 2015.

In order to put these numbers in context, comparisons may be made with previous studies on Burundi. For instance, using data from Burundi’s 1998 Priority Survey, Bundervoet (2010) finds that the average household livestock in provinces strongly affected by war was 0.68 TLUs,

\footnotetext{
${ }^{2}$ These weights are somewhat standard in the literature, but there are some variations across studies. Slight variation in these weights (e.g. using 0.2 for goats), does not change the main results of the paper.
} 
while in other provinces, it was $0.62 .{ }^{3}$ He does not provide details about the average number of adults per household in the sample, but if we divide his reported average household livestock by the average number in our sample (i.e., 3.3), we get a TLU per adult that is between 0.19 and 0.21 for his sample. This number is similar to the average for stayees in our sample across periods. This suggests that, based on the limited information available, there has not been much growth in livestock levels in Burundi over time.

In Table 1, we also show mean differences in other related variables that confirm the gap in economic conditions between stayee and returnee households. The first variable indicates the subjective situation of the household. It is based on a five-point scale, from "Finding it very difficult" (1) to "Living very comfortably" (5). The average of the answers for each group is very consistent across periods, and in both cases, returnees report lower values. The second variable reports on the subjective situation of the household relative to other households in the community. Again, it is based on a five-point scale from "Amongst the poorest in the community" to "Among the richest in the community." Returnee households also report lower values for this question. In the empirical estimation, we also show results using these two subjective measures as the dependent variables.

\subsection{Regression equation}

We estimate a series of regressions along the following lines:

$$
Y_{i}=\delta_{i}+\beta R_{i}+\theta X_{i}+\varepsilon_{i}
$$

where $Y_{i}$ is the outcome of interest for household $i, \delta_{i}$ is the province dummy, $X_{i}$ is a series of household and community level controls, and $\varepsilon_{i}$ is the random error. The outcomes of interest are those presented at Table 1, particularly livestock levels measured in TLUs per adult. The variable

\footnotetext{
${ }^{3}$ Provinces strongly affected by the conflict at the time were Bubanza, Bujumbura rural, and Cibitoke.
} 
$R_{i}$ indicates a returnee household. The coefficient of interest for the analysis is $\beta$. We present results using each round of the survey separately and together. In estimations in which we pool both rounds of the survey, we add a time dummy. All estimations include robust standard errors.

We explore results using different specifications of $R_{i}$ at the household level. First, we use a dummy, indicating that at least one member of the household is a returnee. Second, we use the share of household members who are returnees. We tried other variations, such as a dummy variable, to indicate that the head of the household is a returnee, and results are robust to these variations in definition. Table 2 provides descriptive statistics for the control variables included in $X_{i}$.

[Table 2]

\subsection{Instrumental variable}

As explained above, the large majority of refugees returned to Burundi in the 2000s (Harild et al., 2015; Ruiz and Vargas-Silva, 2016). Hence, selection in terms of return migration (i.e., returning or staying) is unlikely. Moreover, the large majority of returnees returned to their region of birth (Fransen, 2015; Kirchhof, 2009).

Substantial evidence also indicates that exposure to conflict in Burundi was random (Uvin, 1999; Voors et al., 2012). Fearing for their safety, Hutus launched pre-emptive attacks against members of the Tutsi-dominated army and Tutsi civilians. The army was unable to properly identify rebels and launched indiscriminate attacks against the population to demonstrate power and used fear as a method of control (Krueger and Krueger, 2007).

We use information from the community survey to control for conflict exposure. However, even if exposed to the same level of conflict, some individuals might be more likely 
than others to move abroad in order to escape conflict. As such, one possibility of bias in our case relates to the likelihood of being an international migrant in the first place.

The literature on forced displacement suggests that, even if random conflict is the main driver of emigration, those individuals from better off families can travel further and select better locations (Van Hear, 2006). Therefore, the returnees in our sample could have come from better off households in the pre-conflict period. We further explore the role of pre-war livestock in this section and the robustness section. However, there could be other related, unobserved factors that affect the likelihood of being a returnee or having a returnee as a member of the household. In order to control for this possibility, we need an exogenous factor that affects the likelihood of being an international migrant.

In the estimation, we use the logarithm of the inverse of distance to the border of Tanzania at birth (proximity) as an instrument to measure the likelihood of being a refugee/returnee. In Burundi most of the displacement occurred by foot and distance to the border is likely to affect the probability of being a migrant/returnee. As shown in Table 3, the average distance is 57 kilometers, but there is substantial variation in this number from 1.9 kilometers to 147 kilometers.

Table 3 also reports the results of the first stage estimations. The results suggest that proximity to the border has a strong positive effect on the likelihood of being a returnee. The coefficient suggests that a 10 percent increase in the inverse of distance would increase the likelihood of being a returnee by about 2 percentage points. The value of the $F$-test of the excluded instrument test is also very high.

[Table 3] 
If exposure to conflict was random as argued by previous studies, then we would expect individuals to be displaced roughly evenly across the country, with those close to the border becoming international refugees, while those further away being internally displaced. We do not have a perfect measure of internal displacement in the survey, but we have several related measures that can validate this possibility. First, we have a variable which indicates that at least one member of the household was displaced for three consecutive months within Burundi. While this variable is somewhat similar to our measure of international displacement, we will not capture many of those who moved within Burundi for security/conflict reasons and did not consider themselves to be in a situation of "displacement" (e.g. those who changed community of residence permanently). Second, we have a variable which indicates that at least one member of the household spent three months in a displacement camp within Burundi. This variable has the same shortcoming of the first variable, but it is more limited as it does not capture displacement in non-camp situations. Table 4 presents the impact of proximity on these two measures of internal displacement. ${ }^{4}$ In all cases the coefficient is negative as expected, but it is only significant for the case of the variable measuring all types of displacement. As explained above, this variable is better at capturing internal displacement experiences.

[Table 4]

The main concern about the instrument is that proximity may relate to unobserved factors that affect household wealth or economic activities. We conduct several analyses to explore this possibility. First, for older households, i.e., those that were established before the start of the conflict in 1993, we collected pre-conflict livestock data. This measure is in TLUs. As explained by Bundervoet (2010), there was a significant decrease in livestock levels in Burundi as a result of the war. However, pre-war livestock levels should provide a good idea of the household's

\footnotetext{
${ }^{4}$ The analysis follows a similar approach to that of Table 3.
} 
economic background. As shown in the first column of Table 5, there is no statistically significant relationship between proximity and pre-war livestock. While the measure of preconflict livestock is informative, caution should be exercised while interpreting results with this variable. The information is subject to substantial error given the long recollection period. ${ }^{5}$

Another possibility is to look at education levels. Primary education in Burundi is compulsory for children between the ages of 7 and 12. However, the war destroyed a quarter of the country's schools, a significant portion of the teaching staff was killed, and recruitment of new teachers was interrupted during the conflict (US Department of Labor, 2001). We focus on the years of education among those who were 14 years of age and older at the start of the conflict in 1993. The war should not have affected the educational outcomes (i.e., primary school education) of this group. As shown in Table 5, there is no significant impact of proximity on years of education or the likelihood of finishing primary school.

In addition, we can use information from the survey on the main economic activities of returnees just before migration. Given that this specific information was only collected for a subsample of returnees, i.e., one adult returnee per household, and there is no comparable information for stayees, we can test the relationship of economic activities just before migration and proximity to the border only for some returnees. As shown in columns 3, 4 and 5 of Table 5, there is no significant relationship between proximity to Tanzania and pre-migration economic activities.

[Table 5]

\section{Impacts on livestock and related economic indicators}

\footnotetext{
${ }^{5}$ See Beegle et al. (2012) for a discussion of the impact of recollection period on measurement.
} 
Table 6 reports the impact of being a returnee household on livestock levels. The OLS estimates (columns 1, 4 and 7) suggest that the effect is negative and significant for all periods. The coefficient using the two rounds of the survey (column 7) suggests that that, on average, a household with at least one returnee has a livestock per adult that is approximately 0.04 TLU smaller than the average stayee household. This is a $20 \%$ reduction in TLUs compared to the mean value for stayees. Results for the IV 2SLS estimations are presented in columns 2, 5 and 9. The effect is not significant for the IV 2SLS estimation in the first period (column 2). However, the coefficient for the IV estimation using both rounds is significant (column 9) and suggests that, on average, a household with at least one returnee has a livestock per adult that is approximately 0.16 TLU smaller than the average stayee household, which is broadly the equivalent in TLUs to one goat per adult household member (or an $80 \%$ reduction in TLUs compared to the mean value for stayees). These results suggest a very large livestock gap between returnee and stayee households in rural Burundi.

We also include an estimation with fixed effects at the colline level in column 8 of Table 6. The coefficients are similar to those obtained from the regular OLS estimation, but are a bit less significant. However, we still find that there is a statistically significant difference in livestock between returnees and stayees.

In Table 6 we also show the results from an alternative estimation using an endogenous binary-variable model. Although widely used in this type of estimations, the IV 2SLS ignores the binary nature of the variable that is being instrumented. While limited in other ways, the endogenous binary-variable model has the advantage to address the binary nature of this 
variable. ${ }^{6}$ The results in columns 3, 6 and 12 of Table 6 suggest that accounting for the binary nature of the instrumented variable in this model results in the coefficient being significant in all periods. The estimated impact (i.e. size of the coefficient) of household returnee status on livestock is similar to the results from the IV 2SLS.

[Table 6]

Table 6 also shows the results when we use the subjective well-being measures as the dependent variables. Returnee households have a lower subjective economic well-being than stayee households. When looking at the perceived well-being relative to other households in the community, there is somewhat less significance in the results; however, using both rounds of the survey, it is still the case that returnee households are worse off in these estimations.

\section{The role of economic activities during and after migration}

As we explained above, due to deterioration/degradation of skills, a migrant's inactivity while abroad can have implications for income generation upon returning to the home country. In this section, we examine information on economic activities to shed some light on this possibility.

One adult returnee per household was randomly selected during the data collection for a separate, in-depth interview about experiences before, during and just after migration. This information includes the economic activities of individuals during those periods. The top portion of Table 7 summarizes the main economic activities of returnees while abroad, while the bottom portion provides information on activities just before migration. Please note that the information is for the pre-migration period, not for the pre-war period. As such, pre-migration activities could have been affected by the conflict. Column (1) contains information on the main economic

\footnotetext{
${ }^{6}$ We use the etregress command in STATA and estimate the model by maximum likelihood with a constant. See Section 21.4.1 of Chapter 21 of Woodridge (2010) for further details of the model and estimation.
} 
activity, while column (2) reports on all economic activities. In column (2), we are also able to separate agricultural employees from non-agricultural employees.

Close to one third of the returnees with available information were inactive while abroad compared to only $11 \%$ just before migration. This high level of inactivity among migrants in the context of forced displacement has also been documented in other contexts (e.g., Lehrer, 2010) and correspond well with accounts about the dependence of refugees on food rations from international agencies, as well as the legal restrictions that refugees faced for working outside the camps (Harild et al., 2015; West and Wambugu, 2003). Additionally, the share of employees who engaged in agricultural work while abroad is substantially higher than it was prior to migration. Finally, while farming for subsistence was very important for returnees in the premigration period (main activity of $71 \%$ of respondents), this was not the case during migration (main activity of only $23 \%$ of respondents). Again, this coincides well with the legal limitations for Burundian refugees to cultivate plots while in Tanzania. Please note again that we do not have comparable "pre-migration" information for stayees. As such, it is not possible to conduct a formal test of changes over time between the two groups.

\section{[Table 7]}

We cannot test the implications of past labor market experiences on current livestock levels because we only have pre-migration information for a sub-set of returnees, and there is no comparable situation for stayees. Additionally, we do not have good data on current income in the survey. Given the rural nature of the region, compensation for work is often provided by payment in-kind, and there is a strong reliance on farming for subsistence. However, we can still look at current economic activities to determine if there are major differences between returnees and stayees in this regard. 
In Table 8, we present the impact of returnee status on current main economic activity. In addition to the household controls explained above, we add individual controls for marital status, gender, age, education and IDP status of the individual. The results suggest that being a returnee has a negative impact on being self-employed as the main activity. This result contrasts with the evidence from the "economic" migration context in which returnees often have a higher likelihood of being self-employed (e.g., McCormick and Wahba, 2001). On the other hand, returnees have a significantly higher chance of having farming as their main economic activity, evidenced by a gap of approximately 24 percentage points.

\section{[Table 8]}

The main economic activity does not provide the whole story. Given the importance of farming for subsistence in Burundi, it is important to look at all economic activities. It is also important to separate agricultural and non-agricultural employees. This information is not available in the 2011 round of the survey. As such, we can only conduct this estimation using the information from the 2015 round. Table 9 explores activity participation, as we allow the individuals to participate in more than one activity. Being a returnee has a strong positive impact on the likelihood of being an agricultural worker and subsistence farming. On the other hand, the coefficients for self-employment and being a non-agricultural employee are negative but not significant.

[Table 9]

Overall, if agricultural activities result in less income than other economic activities, the greater tendency of returnees to depend on the agricultural sector (for subsistence in their own plots or as employees) and the lower likelihood of their self-employment could explain some of the observed livestock differences between returnee and stayee households. In order to explore 
this possibility, in Table 10, we provide the average household livestock levels by economic activity for stayees. By using stayees, without worrying about the possible effects of migration, we get a good idea of the overall livestock consequences of choosing certain economic activities. While we cannot claim any causal effects from the results in Table 10, it is clear that those in self-employment and non-agricultural employment live in households with higher livestock levels per adult. Meanwhile, those stayees in agricultural employment and farming, the two activities in which returnees had a higher likelihood of participating, live in households with lower average livestock levels per adult.

[Table 10]

One aspect that we cannot explore with the available data, but that can create further differences between returnees and stayees, particularly among the self-employed, is the likelihood of being a "necessity" versus "opportunity" entrepreneur. Refugees who return home, particularly those who are forced to return, could be likely to become necessity entrepreneurs as they have less options available. As suggested by previous studies, this has important implications because it is opportunity entrepreneurs and not necessity entrepreneurs the ones that often tend to be more successful (Amin, 2010). This is an important gap in the evidence to which future studies can contribute.

\section{The role of household vulnerability}

Another possible explanation for the livestock differences between returnee and stayee households is that returnee households are more vulnerable than stayee households. This vulnerability could be reflected in factors such as exposure to crime or health complications. With some family members abroad, there could have been less protection of livestock and other assets and therefore, greater exposure to theft. As explained by Bundervoet (2009), livestock is a 
particularly easily lootable form of wealth in Burundi. In addition, a substantial amount of literature also documents the adverse effects of forced displacement on health outcomes (e.g., Ortiz Becerra, 2014; Thomas and Thomas, 2014). Returnee households with poorer health may not be able to accumulate wealth as fast as other households.

In the survey, there are questions about thefts of livestock, cash, agricultural tools and other assets since 2005. As suggested by the results in Table 11, there is not a statistically significant difference between returnee and stayee households in the likelihood of experiencing theft of livestock, tools or other assets. Interestingly, returnee households are less likely to experience cash thefts. Of course, returnee households may be less likely to hold cash in the first place. We also conduct the estimation using a dependent variable that indicates any theft, and the result was insignificant (not shown).

The survey also includes questions about any instances of serious illnesses among the adult household members since 2005. For adults, the questions are asked separately by gender. As shown in Table 11, returnee households are significantly less likely to have reported having household members who experienced a serious illness. The results hold separately for adult males and adult females, but in the case of children, there is no significant difference.

Overall, there is no evidence that a greater vulnerability among returnee households in terms of criminality or health outcomes helps to explain the gap in livestock levels between stayee and returnee households.

[Table 11]

\section{Time since return and time abroad}

As shown in Figure 5, there were two key periods in the return process. First, there are returnees who came back after a brief stay abroad, shortly after the conflict ensued. That period goes from 
1993 to 1999 , with a substantial peak in 1994 . The second period starts after the signature of the peace agreement in 2000, extending to 2010. The peak for this second period was 2005 .

There could be important differences in economic outcomes between early and late returnees. First, it could be possible that returnee households are catching up over time with stayee households. As such, we would expect those that returned in the 1990s to be better off than those that returned in the 2000s. Also, the bulk of the economic restrictions on Burundians from the Tanzanian government were implemented during the late 1990s and, as such, early returnees are less likely to have been affected by these policies. Finally, those who returned early were mostly "voluntary" returnees, while most of those returning later were "pushed-out" by the Tanzanian government. Many of these later returnees experienced forced displacement to Tanzania and forced return to Burundi.

[Figure 5]

In the 2011 round, the median number of years since return was 10 years. In order to test the importance of time since return, we create two dummy variables. One variable indicates a household with members who returned from abroad less than ten years ago in 2011 (i.e., less than 14 years ago in 2015). The second variable indicates that it is a household with members who returned ten or more years ago in 2011 (i.e., 14 years or more in 2015). The top portion of Table 12 presents the results when we use these dummy variables in the estimations (separate estimations). The results suggest that the negative effect of the returnee household variable on livestock levels is driven by households with more recent returnees. ${ }^{7}$ However, please recall that the estimated differences between returnees and stayees in Table 6 were smaller for the first

\footnotetext{
${ }^{7}$ As an additional exercise, we limited the sample to households with returnees and estimated the impact of an additional year after return on livestock. The impact is small at around 0.003 TLUs per adult per year, but the coefficient is insignificant.
} 
round of the survey. As such, while the results in Table 12 provide some indication of catching up over time, the overall evidence is not fully conclusive.

[Table 12]

The implication of return migration may also vary depending on the amount of time spent abroad. Some migrants only stay a few months (at least three in our definition), while others stay for over a decade. In order to analyze these possibilities, we create dummy variables to indicate that members of the household stayed abroad for less/more than a decade. In the bottom portion of Table 12, we analyze the impact of time spent abroad on livestock outcomes. Unsurprisingly, those households with members who stayed longer abroad have worse outcomes.

\section{Propensity Score Matching and pre-war livestock}

In this section, we test the robustness of the results by employing propensity score matching (PSM) techniques in order to match returnee households with a comparable group of nonreturnee households. In this case, the treatment $(T)$ is a returnee household. As we explained above, the large majority of refugees from the 1993-2000 conflict returned home after the end of the war. Hence, the treatment is essentially being a refugee in the first place, a factor that was largely determined by distance from the border of Tanzania.

We start by estimating a probit model to predict the likelihood of being a returnee household based on pre-war characteristics, and then we match households based on treatment status. We limit the analysis to households in which the household head was born before the start of the conflict in 1993. The pre-war characteristics include age, gender and province of birth of the household head, education levels of those household members who were adults before 1993 (i.e., 14 years of age or more), and pre-war livestock. These factors should not be affected by the treatment. Once we check for the balancing properties and common support across the treatment 
and comparison group, we proceed to use the nearest neighbor estimation matching procedure. With the matching at hand, the difference in the outcome variable is calculated to estimate the average treatment effect of the treated.

Table 13 shows the results for the estimated effect of displacement and return on household livestock. As with the IV estimations, there is evidence that returnee households have lower livestock levels compared to stayee households. However, unlike the IV estimations, it seems that the difference is greater and statistically significant for the first period only. One possible explanation for this is that the matching is based on pre-war characteristics only, which are likely to become less important over time.

[Table 13]

\section{Conclusions}

The world is currently experiencing global records of forced displacement. Over time, many of these forced migrants will return home. Knowledge about the implications of migrant return in the conflict context is essential in order to develop adequate policies in the post-conflict period.

In this paper, we explore differences in economic outcomes between return migrant households and stayee households using longitudinal data from Burundi, a country that experienced large scale conflict-led emigration and massive post-war refugee return. The results indicate that returnee households have significantly lower levels of livestock, which is the main

form of capital accumulation in the country. Returnee households also report lower values of subjective economic well-being relative to other households. Our search for explanations supports the idea that returnees are more likely to engage in activities that are correlated with lower levels of livestock. One possible reason relates to the legal and practical restrictions on economic activities while in displacement, which resulted in high levels of inactivity and a 
potential loss/deterioration of skills. However, this explanation remains tentative as we do not have equivalent "pre-migration" information for stayees to conduct a formal test. Other factors such as incomplete restitution of land to returnees can also play a major role. Some of the results suggests that the economic gap between returnee and stayee households is driven by more recent returnees, i.e., less than ten years since return. However, the evidence about "catching up" is not fully conclusive.

A key result from this paper is that the economic dynamics of returnees in the conflict context are substantially different from the evidence in the "economic" migration context. In the conflict context, migration and return could take place even when not economically beneficial, leading to a substantial negative economic gap between migrants and non-migrants. Our results highlight the importance of allowing refugees the opportunity to engage in employment and other economic activities while in displacement and the need for continuous support after returning home.

Finally, it is important to note that the results of this study might not be applicable to other circumstances, as we look at refugees who were primarily in a situation of encampment, with legal restrictions on movement and economic activities, many of whom were required to return home by the host country and were returning to one of the poorest countries in the world. The consequences of return could be different in situations in which refugees are integrated into the host economy and have the option of staying permanently. 


\section{References}

Amin, M. 2010. "Necessity vs. Opportunity Entrepreneurs in the Informal Sector”, World Bank Enterprise Note Series, 60351. World Bank: Washington, DC.

Barrett, A. and Goggin, J. 2010. "Returning to the Question of a Wage Premium for Returning Migrants”, National Institute Economic Review 213(1), pp. 43-51.

Black, R. and Koser, K. 1999. "The End of the Refugee Cycle?" Chapter 1 in Black, R. and Koser, K. eds. The End of the Refugee Cycle? Refugee Repatriation and Reconstruction. Berghahn Books, Oxford.

Beegle, K., De Weerdt, J., Friedman, J. and Gibson, J. 2012. "Methods of Household Consumption Measurement through Surveys: Experimental Results from Tanzania”, Journal of Development Economics, 98(1), pp. 3-18.

Bundervoet, T. 2009. "Livestock, Land and Political Power: The 1993 Killings in Burundi", Journal of Peace Research, 46(3), pp. 357-376.

Bundervoet, T. 2010. “Assets, Activity Choices, and Civil War: Evidence from Burundi”, World Development, 38(7), pp. 955-965.

Bundervoet, T., Verwimp, P. and Akresh, R. (2009) "Health and Civil War in Rural Burundi”, Journal of Human Resources, 44(2), pp. 536-563. 
Chin, A. (2005) "Long - Run Labor Market Effects of Japanese American Internment during World War II on Working - Age Male Internees”, Journal of Labor Economics 23(2), pp. 491525.

Co, C.Y., Gang, I.N. and Yun, M. 2000. "Returns to Returning", Journal of Population Economics 13(1), pp. 57-79.

Durieux, J-F. 2008. 'Interview with UNHCR's Jean-François Durieux: A Career Working for Refugees", Studies in Ethnicity and Nationalism, 8(2), 331-347.

Dustmann, C., Fadlon, I. and Weiss, Y. 2011. "Return Migration, Human Capital Accumulation, and the Brain Drain”, Journal of Development Economics, 95(1), 58 - 67

Dustmann, C. and Görlach, J-S. 2016. "The Economics of Temporary Migrations”, Journal of Economic Literature, 54(1), pp. 98 - 136.

Dustman, C. and Kirchkamp, O. 2002. "The Optimal Migration Duration and Economic Activities after Re-Migration”, Journal of Development Economics, 67(2), pp. 351-372.

Enghoff, M., Hansen, B., Umar, A., Gildestad, B., Owen, M. and Obara, A. 2010. "In Search of Protection and Livelihoods: Socio-Economic and Environmental Impacts of Dadaab Refugee Camps on Host Communities”. Danish Refugee Council: Copenhagen. 
European Commission. 2009. "Burundi Refugees Face Deadline to Return Home. Q\&A with Eric Pitois, Head of Burundi/Tanzania Office”. European Commission: Brussels.

Fransen, S. 2015. "The Socio-Economic Sustainability of Refugee Return: Insights from Burundi”, Population, Space and Place, early view, DOI: DOI: 10.1002/psp.1976.

Fransen, S. and Kuschminder, K. 2012. "Back to the Land: The Long-Term Challenges of Refugee Return and Reintegration in Burundi”, New Issues in Refugee Research, 242.

Harild, N., Christensen, A. and Zetter, R. 2015. "Sustainable Refugee Return: Triggers, Constraints, and Lessons on Addressing the Development Challenges of Forced Displacement", World Bank, GPFD Issue Note Series. World Bank: Washington, DC.

Hainmueller. J., Hangartner, D. and D. Lawrence (2016) "When Lives are Put on Hold: Lengthy Asylum Processes Decrease Employment Among Refugees.” Science Advances, 2(8).

Ibañez, A. M. and Velez, C. E. 2008 "Civil Conflict and Forced Migration: The Micro Determinants and Welfare Losses of Displacement in Colombia", World Development, 36(4), pp. 659-676.

Kamanga, K. 2005. "The (Tanzania) Refugees Act of 1998: Some Legal and Policy Implications", Journal of Refugee Studies, 18(1), pp. 100-116. 
Kirchhof, A. 2009. "Burundi: Seven Years of Refugee Return”, Forced Migration Review, 33.

Krueger, R. and Krueger, K.T. 2007. From Bloodshed to Hope in Burundi: Our Embassy Years during Genocide. University of Texas Press.

Lehrer, K. 2010. Economic Behaviour During Conflict: Education and Labour Market Participation in Internally Displaced People's Camps in Northern Uganda (doctoral dissertation). University of British Columbia.

Maystadt, J. and Verwimp, P. 2014. "Winners and Losers Among a Refugee-Hosting Population”, Economic Development and Cultural Change, 62(4), pp. 769-809.

McCormick, B. and Wahba, J. 2001. "Overseas Work Experience, Savings and Entrepreneurship Amongst Returnees to LDCs", Scottish Journal of Political Economy 48(2), pp. 164-178.

Mesnard, A. 2004. "Temporary Migration and Capital Market Imperfections", Oxford Economic Papers, 56(2), pp. 242-262.

Millner, J. 2013. "Two Steps Forward, One Step Back: Understanding the Shifting Politics of Refugee Policy in Tanzania”, New Issues in Refugee Research, no. 255. 
Ngaruko, F. and Nkurunziza, J. 2000. "An Economic Interpretation of Conflict in Burundi”, Journal of African Economies, 9(3), pp. 370-409.

O’Reilly, C. 2015. "Household Recovery from Internal Displacement in Northern Uganda”, World Development”, 76, pp. 203-215

Ongpin, P. 2008. "Refugees in Tanzania - Asset or Burden?”, Journal of Development and Social Transformation, 5, pp. 13-23.

Ortiz Becerra, K. 2014. "Forced Displacement and Early Childhood Nutritional Development in Colombia", Households in Conflict Network, Working Paper, 180.

Piracha, M. and Vadean, F. 2010. "Return Migration and Occupational Choice: Evidence from Albania”, World Development, 38(8), pp. 1141 - 1155.

Reinhold, S. and Thom, K. 2013. "Migration Experience and Earnings in the Mexican Labor Market”, Journal of Human Resources, 48(3), pp. 768-820.

Ruiz, I., Siegel, M. and Vargas-Silva, C. 2015. "Forced Up or Down? The Impact of Forced Migration on Social Status”, Journal of Refugee Studies, 28(2), pp. 183-201.

Ruiz, I. and Vargas-Silva, C. 2013. "The Economics of Forced Migration”, Journal of Development Studies, 49(6), pp. 772-784. 
Ruiz, I. and Vargas-Silva, C. 2015. “The Labor Market Impacts of Forced Migration”, American Economic Review, 105(5): 581-586.

Ruiz, I. and Vargas-Silva, C. 2016. "The Labor Market Consequences of Hosting Refugees", Journal of Economic Geography, 16(3), pp. 667-694.

Thomas, S.L. and Thomas, S. 2004. "Displacement and Health”, British Medical Bulletin, 69(1), pp. $115-127$.

United Nations Development Programme. 2015. Human Development Report. UNPD: New York.

United Nations High Commission for Refugees. 2008. "Burundian Refugee Returns from Tanzania Hit 300,000 Mark”. Briefing Notes. UNHCR: Geneva.

United Nations High Commission for Refugees. 2009. “Global Appeal 2008/2009”. UNHCR: Geneva.

United Nations High Commission for Refugees. 2015a. "UNHCR and partners appeal for US\$207 million for Burundi Emergency”. UNHCR: Geneva. 
United Nations High Commission for Refugees. 2015b. "Burundi Refugee Situation in Tanzania

- Daily Statistical Report - 11 November 2015”. UNHCR: Geneva.

United Nations High Commission for Refugees. 2016. “Global Trends in Forced Displacement in 2015". UNHCR: Geneva.

US Department of Labor. 2001. "Burundi" in Findings on the Worst Forms of Child Labor, Department of Labor: Washington, DC.

Uvin, P. 1999. "Ethnicity and Power in Burundi and Rwanda: Different Paths to Mass Violence”, Comparative Politics 31(3), pp. 253-271.

Van Hear, N. 2006. “'I Went as Far as my Money would Take Me’: Conflict, Forced Migration and Class" Centre on Migration, Policy and Society, Working Paper No. 6.

Verwimp, P., Muñoz-Mora, J.C. 2013 "Returning Home after Civil War: Food Security, Nutrition and Poverty among Burundian Households" Households in Conflict Network, Working Paper 123.

Verwimp, P., Van Bavel, J. 2014. "Schooling, Violent Conflict and Gender in Burundi”, The World Bank Economic Review, 28(2), pp. 384-411. 
Voors, M. J., Nillesen, E., Verwimp, P., Bulte, E., Lensink, H., and Van Soest, D. 2012. "Violent Conflict and Behavior: A Field Experiment in Burundi”, American Economic Review, 102(2), pp. $941-964$.

Vorrath, J. 2008. "From Refugee Crisis to Reintegration Crisis? The Consequences of Repatriation to (post) Transition Burundi.” L’Afrique des Grands Lacs (Paris), 12, pp. 109-127.

Wahba, J. 2015a. “Who Benefits From Return Migration to Developing Countries?”, IZA World of Labor, 123.

Wahba, J. 2015b. "Selection, Selection, Selection: The Impact of Return Migration”, Journal of Population Economics, 28(3), pp. 535-563.

West, A. and Wambugu, L.W. 2003. "Left to Their Own Devices: The Impact of Informal Information and Communication Networks on Security in the Tanzanian Refugee Camps", Article 19 Report. Article 19: London, UK.

Whitaker, B.E. 2002. "Refugees in Western Tanzania: The Distribution of Burdens and Benefits among Local Hosts”, Journal of Refugee Studies, 15, pp. 339-358.

Zetter, R. and Ruaudel, H. 2016. "Refugees' Right to Work and Access to Labor Markets - An Assessment”, KNOMAD Working paper. World Bank: Washington, DC. 
Wooldridge, J. 2010. Econometric Analysis of Cross Section and Panel Data. MIT Press, Cambridge, MA.

World Bank. 2015. “Burundi Economic Indicators”. World Bank: Washington, DC.

Yang, D. 2006. "Why Do Migrants Return to Poor Countries? Evidence from Philippine Migrants' Responses to Exchange Rate Shocks", Review of Economics and Statistics, 88(4), pp. $715-735$. 


\section{Appendix 1}

\begin{tabular}{ll}
\hline Variable & Definition \\
\hline & Livestock index from 0 to 1 based on the following weights: cow $/$ ox $=1,1$ \\
Livestock & sheep $=0.17,1$ goat $=0.17,1$ pig $=0.25$ and 1 fowl $=0.01$. It is divided by \\
& the number of adult members of the household. Adult $=14$ years of age or \\
& older.
\end{tabular}

Employee

Self-employment

Farming

Theft livestock

Theft cash

Theft agricultural tools

Theft other assets

Illness women
Dummy equal to one if the individual worked for someone outside the household as an employee during the last 12 months.

Dummy equal to one if the individual worked as self-employed (not including farming) during the last 12 months.

Dummy equal to one if the individual worked in farming for subsistence during the last 12 months.

Dummy equal to one if the household experienced any livestock thefts during 2005-2011.

Dummy equal to one if the household experienced any cash thefts during 2005-2011.

Dummy equal to one if the household experienced any agricultural tools thefts during 2005-2011.

Dummy equal to one if the household experienced thefts of any other assets during 2005-2011 (not including housing).

Dummy equal to one if any adult female member of the household experienced a serious illness during 2005-2011. Adult $=14$ years of age or older. 
Illness men

Illness children

Proximity

Returnee

Returnee household

Share returnees

Female

Age

Primary

Secondary

Married

Household size

Child to adult ratio
Dummy equal to one if any adult male member of the household experienced a serious illness during 2005-2011. Adult $=14$ years of age or older.

Dummy equal to one if any child member of the household experienced a serious illness during 2005-2011. Children $=$ less than 14 years of age.

Logarithm of inverse of distance to Tanzania in kilometers.

Dummy equal to one if the individual was born in Burundi, left the country for security or political reasons (main reason) and spent a least three months living abroad.

Dummy equal to one if any of the household members is a returnee.

Share of household members who are returnees.

Dummy equal to one if the person is female.

Age in years.

Dummy equal to one if the person completed primary schooling.

Dummy equal to one if the person completed secondary schooling.

Dummy equal to one if the person is currently married.

Number of members of the household.

Number of children in the household divided by number of adults in the household. Adult $=14$ years of age or older. Children $=$ less than 14 years of age. 
IDP household

Deaths in conflict
Dummy equal to one if at least one member of the household spent at least three months in displacement within Burundi.

Dummy equal to one if at least $10 \%$ of the residents of the community were killed during the conflict. 
Table 1- Descriptive statistics for current household livestock and related measures.

\begin{tabular}{|c|c|c|c|c|c|c|c|c|c|}
\hline \multirow[b]{2}{*}{ Variable } & \multicolumn{3}{|c|}{ Returnees } & \multicolumn{3}{|c|}{ Stayees } & \multicolumn{3}{|c|}{ t-test of difference } \\
\hline & $\begin{array}{c}2011 \\
(1) \\
\end{array}$ & $\begin{array}{c}2015 \\
(2) \\
\end{array}$ & $\begin{array}{c}2011 \text { and } \\
2015 \\
(3)\end{array}$ & $\begin{array}{c}2011 \\
(4)\end{array}$ & $\begin{array}{c}2015 \\
(5) \\
\end{array}$ & $\begin{array}{c}2011 \text { and } \\
2015 \\
(6)\end{array}$ & $\begin{array}{c}2011 \\
(7) \\
\end{array}$ & $\begin{array}{c}2015 \\
(8)\end{array}$ & $\begin{array}{l}2011 \text { and } \\
2015 \\
(9)\end{array}$ \\
\hline Livestock, TLUs & 0.10 & 0.16 & 0.13 & 0.16 & 0.24 & 0.20 & $-2.69 * * *$ & $-2.82 * * *$ & $-3.85 * * *$ \\
\hline $\begin{array}{l}\text { Current economic situation } \\
(\text { worse }=1 \text { to better }=5 \text { ) }\end{array}$ & 2.34 & 2.35 & 2.34 & 2.49 & 2.48 & 2.49 & $-1.91 *$ & $-1.72 *$ & $-2.58 * * *$ \\
\hline $\begin{array}{l}\text { Relative situation } \\
(\text { worse }=1 \text { to better }=5)\end{array}$ & 2.27 & 2.30 & 2.28 & 2.48 & 2.53 & 2.50 & $-2.55 * *$ & $-2.73 * * *$ & $-3.74 * * *$ \\
\hline Households & 150 & 150 & 300 & 754 & 754 & 1,508 & & & \\
\hline
\end{tabular}

Note: Returnee households are defined as those with at least one member who is a returnee. "Current economic situation" and "Relative situation" are subjective measures of well-being. *** indicates that the difference is significant at the $1 \%$ level. ** indicates that the difference is significant at the $5 \%$ level. * indicates that the difference is significant at the $10 \%$ level. 
Table 2 - Household/community level controls

\begin{tabular}{lcccccc}
\hline & \multicolumn{3}{c}{ Returnees } & \multicolumn{3}{c}{ Stayees } \\
& 2011 & 2015 & 2011 and 2015 & 2011 & 2015 & 2011 and 2015 \\
& $(1)$ & $(2)$ & $(3)$ & $(4)$ & $(5)$ & $(6)$ \\
\hline Age head & 44.41 & 48.03 & 46.22 & 43.74 & 47.76 & 45.75 \\
Female head & 0.18 & 0.15 & 0.16 & 0.16 & 0.16 & 0.16 \\
Primary edu head & 0.19 & 0.25 & 0.22 & 0.24 & 0.30 & 0.27 \\
Secondary edu head & 0.01 & 0.02 & 0.02 & 0.03 & 0.03 & 0.03 \\
Married head & 0.79 & 0.83 & 0.81 & 0.82 & 0.83 & 0.82 \\
Household size & 5.60 & 5.90 & 5.74 & 5.54 & 5.70 & 5.62 \\
Child to adult ratio & 0.94 & 0.92 & 0.93 & 0.84 & 0.86 & 0.85 \\
IDP household & 0.17 & 0.17 & 0.17 & 0.29 & 0.29 & 0.29 \\
Deaths in conflict & 0.43 & 0.43 & 0.43 & 0.44 & 0.44 & 0.44 \\
\hline Net
\end{tabular}

Note: returnee households are those households with at least one member who is a returnee. 
Table 3 -Descriptive statistics of the instrument and first stage results.

\begin{tabular}{|c|c|c|c|c|}
\hline Variable & \multicolumn{4}{|c|}{ Descriptive statistics } \\
\hline & Mean & SD & Min & Max \\
\hline Distance $(\mathrm{kms})$ & 57.11 & 35.03 & 1.87 & 146.7 \\
\hline \multirow[t]{4}{*}{ Proximity } & -3.81 & 0.76 & -4.99 & -0.63 \\
\hline & \multicolumn{4}{|c|}{ First stage } \\
\hline & Returne & household & Share & urnees \\
\hline & \multicolumn{4}{|c|}{2011 round } \\
\hline Proximity & $\begin{array}{c}0.18 * * * \\
(5.09)\end{array}$ & $\begin{array}{c}0.16 * * * \\
(4.83)\end{array}$ & $\begin{array}{c}0.09 * * * \\
(4.72)\end{array}$ & $\begin{array}{c}0.09 * * * \\
(4.59)\end{array}$ \\
\hline F-test IV & 25.94 & 23.79 & 22.27 & 21.08 \\
\hline & \multicolumn{4}{|c|}{2015 round } \\
\hline Proximity & $\begin{array}{c}0.18 * * * \\
(5.09)\end{array}$ & $\begin{array}{c}0.17 * * * \\
(4.85)\end{array}$ & $\begin{array}{c}0.09 * * * \\
(4.73)\end{array}$ & $\begin{array}{c}0.09 * * * \\
(4.74)\end{array}$ \\
\hline F-test IV & 25.95 & 24.18 & 22.33 & 22.48 \\
\hline Proximity & $\begin{array}{c}0.18 * * * \\
(7.23)\end{array}$ & $\begin{array}{c}2011 \text { and } \\
0.17 * * * \\
(6.89)\end{array}$ & $\begin{array}{c}015 \text { round } \\
0.09 * * * \\
(6.71)\end{array}$ & $\begin{array}{c}0.09 * * * \\
(6.65)\end{array}$ \\
\hline F-test IV & 52.34 & 48.66 & 44.99 & 44.20 \\
\hline Household controls & & $X$ & & $X$ \\
\hline
\end{tabular}

Notes: $* * *$ indicates that the coefficient is significant at the $1 \%$ level. Proximity $=$ logarithm of the inverse of distance to the border with Tanzania in kilometers. In estimations in which we pool both rounds of the survey, we add a time dummy. $t$ statistics are included in parenthesis. 
Table 4 - Relationship between proximity and internal displacement (i.e. within Burundi).

\begin{tabular}{|c|c|c|c|c|c|}
\hline \multirow[b]{2}{*}{ Proximity } & \multicolumn{2}{|c|}{$\begin{array}{c}\text { Three months in } \\
\text { displacement }\end{array}$} & \multicolumn{2}{|c|}{$\begin{array}{l}\text { Three months in a } \\
\text { displacement camp }\end{array}$} & \\
\hline & $\begin{array}{l}-0.13 * * \\
(-2.01)\end{array}$ & $\begin{array}{l}-0.04^{*} \\
(-1.90)\end{array}$ & $\begin{array}{l}-0.01 \\
(-0.56)\end{array}$ & $\begin{array}{c}0.00 \\
(-0.16)\end{array}$ & \\
\hline Controls & & $X$ & & $\mathrm{X}$ & \\
\hline Observations & 1,808 & 1,808 & 1,808 & 1,808 & \\
\hline
\end{tabular}


Table 5 - Impact of proximity on pre-war livestock, pre-war education and pre-migration activities.

\begin{tabular}{|c|c|c|c|c|c|c|}
\hline Independent variable & $\begin{array}{l}\text { Pre-war } \\
\text { livestock }\end{array}$ & $\begin{array}{c}\text { Pre-war years } \\
\text { education }\end{array}$ & $\begin{array}{c}\text { Pre-war } \\
\text { primary school }\end{array}$ & $\begin{array}{c}\text { Pre-migration } \\
\text { employee }\end{array}$ & $\begin{array}{c}\text { Pre migration } \\
\text { self-employment }\end{array}$ & $\begin{array}{l}\text { Pre-migration } \\
\text { farming }\end{array}$ \\
\hline \multirow{2}{*}{ Proximity } & -0.04 & 0.008 & -0.04 & -0.04 & -0.01 & 0.08 \\
\hline & $(-0.35)$ & $(0.04)$ & $(-1.02)$ & $(-0.56)$ & $(-0.13)$ & $(0.95)$ \\
\hline Household & $\mathrm{X}$ & $X$ & $X$ & & & \\
\hline Controls & & & & $X$ & $\mathrm{X}$ & $X$ \\
\hline Observations & 446 & 667 & 690 & 124 & 124 & 124 \\
\hline
\end{tabular}

Notes: Pre-war livestock only available for households which were established before the war. Education is for household heads who were 14 years of age or older at the start of the war in 1993. The information on pre-migration activities is only available for one returnee per household. $t$ statistics are included in parenthesis. 
Table 6 - Impact of being a returnee household on livestock (TLUs) and related measures.

\begin{tabular}{|c|c|c|c|c|c|c|c|c|c|c|}
\hline \multirow{2}{*}{$\begin{array}{l}\text { Independent } \\
\text { variable }\end{array}$} & \multicolumn{3}{|c|}{2011} & \multicolumn{3}{|c|}{2015} & \multicolumn{4}{|c|}{2011 and 2015} \\
\hline & (1) & (2) & (3) & (4) & (5) & (6) & (7) & (8) & (9) & (10) \\
\hline & \multicolumn{10}{|c|}{ Livestock (TLUs per adult) } \\
\hline Returnee & $-0.03^{*}$ & -0.09 & $-0.14 * * *$ & $-0.05^{* *}$ & $-0.23^{* *}$ & $-0.25 * * *$ & $-0.04 * * *$ & $-0.04 * *$ & $-0.16^{* *}$ & $-0.19 * * *$ \\
\hline household & $(-1.71)$ & $(-0.88)$ & $(-3.03)$ & $(-2.34)$ & $(-2.20)$ & $(-5.37)$ & $(-2.88)$ & $(-2.36)$ & $(-2.15)$ & $(-6.04)$ \\
\hline & -0.05 & -0.17 & - & $-0.10^{* *}$ & $-0.44 * *$ & - & $-0.07 * *$ & $-0.06^{*}$ & $-0.30^{* *}$ & - \\
\hline \multirow{2}{*}{ returnees } & $(-1.33)$ & $(-0.87)$ & - & $(-2.04)$ & $(-2.08)$ & - & $(-2.42)$ & $(-1.85)$ & $(-2.09)$ & - \\
\hline & \multicolumn{10}{|c|}{ Current economic situation (worse to better) } \\
\hline Returnee & $-0.15^{*}$ & $-1.10 * *$ & $-0.50^{*}$ & -0.09 & -0.55 & $-0.73 * *$ & $-0.12 * *$ & -0.12 & $-0.80 * *$ & $-0.55^{* *}$ \\
\hline household & $(-1.85)$ & $(-2.42)$ & $(-1.65)$ & $(-1.15)$ & $(-1.19)$ & $(-2.35)$ & $(-2.14)$ & $(-1.59)$ & $(-2.51)$ & $(-2.20)$ \\
\hline Share & $-0.38 * *$ & $-2.06 * *$ & - & -0.26 & -1.06 & - & $-0.31 * *$ & $-0.31 *$ & $-1.53^{* *}$ & - \\
\hline \multirow[t]{2}{*}{ returnees } & $(-2.08)$ & $(-2.41)$ & - & $(-1.37)$ & $(-1.15)$ & - & $(-2.39)$ & $(-1.87)$ & $(-2.44)$ & - \\
\hline & \multicolumn{10}{|c|}{ Economic situation relative to other households in the community (worse to better) } \\
\hline Returnee & $-0.24 * * *$ & -0.65 & -0.26 & $-0.19^{* *}$ & -0.72 & $-0.70 * *$ & $-0.22 * * *$ & $-0.19 * *$ & $-0.66 * *$ & $-0.50^{*}$ \\
\hline household & $(-2.90)$ & $(-1.53)$ & $(-0.87)$ & $(-2.13)$ & $(-1.45)$ & $(-2.50)$ & $(-3.60)$ & $(-2.56)$ & $(-2.02)$ & $(-1.87)$ \\
\hline Share & $-0.51 * * *$ & -1.21 & - & -0.31 & -1.39 & - & $-0.40 * * *$ & $-0.36^{* *}$ & $-1.26^{* *}$ & - \\
\hline returnees & $(-2.71)$ & $(-1.55)$ & - & $(-1.33)$ & $(-1.39)$ & - & $(-2.71)$ & $(-1.96)$ & $(-1.98)$ & - \\
\hline Controls & $\mathrm{X}$ & $\mathrm{X}$ & $\mathrm{X}$ & $\mathrm{X}$ & $\mathrm{X}$ & $\mathrm{X}$ & $\mathrm{X}$ & $\mathrm{X}$ & $\mathrm{X}$ & $\mathrm{X}$ \\
\hline Fixed effects & & & & & & & & $\mathrm{X}$ & & \\
\hline IV 2SLS & & $\mathrm{X}$ & & & $\mathrm{X}$ & & & & $\mathrm{X}$ & \\
\hline Binary & & & $\mathrm{X}$ & & & $\mathrm{X}$ & & & & $X$ \\
\hline Observations & 904 & 904 & 904 & 904 & 904 & 904 & 1,808 & 1,808 & 1,808 & 1,808 \\
\hline
\end{tabular}

Notes: table shows results from separate regressions. "Returnee household" = at least one household member is a returnee. "Share returnees" $=$ share of household members who are returnees. $* * *$ indicates that the coefficient is significant at the $1 \%$ level. $* *$ indicates that the coefficient is significant at the 5\% level. * indicates that the coefficient is significant at the $10 \%$ level. $\mathrm{t}$ statistics are included in parenthesis. In estimations in which we pool both rounds of the survey, we add a time dummy. 
Table 7 - Economic activities of returnees during and just before migration

\begin{tabular}{|c|c|c|}
\hline Variable & Main activity & All activities \\
\hline & \multicolumn{2}{|c|}{ During migration } \\
\hline Employee & 0.31 & 0.50 \\
\hline Agricultural employee & & 0.38 \\
\hline Non-agricultural employee & & 0.12 \\
\hline Self-employment & 0.08 & 0.14 \\
\hline Farming & 0.23 & 0.27 \\
\hline Education & 0.04 & - \\
\hline \multirow[t]{2}{*}{ Other/inactive } & 0.34 & 0.29 \\
\hline & \multicolumn{2}{|c|}{ Pre-migration } \\
\hline Employee & 0.09 & 0.24 \\
\hline Agricultural employee & & 0.15 \\
\hline Non-agricultural employee & & 0.09 \\
\hline Self-employment & 0.05 & 0.17 \\
\hline Farming & 0.71 & 0.79 \\
\hline Education & 0.04 & - \\
\hline Other/inactive & 0.11 & 0.10 \\
\hline Individuals & 124 & 124 \\
\hline
\end{tabular}

Note: information based on the in-depth interview and collected only for one adult returnee per household. 
Table 8 - Impact of being a returnee on economic activities.

\begin{tabular}{|c|c|c|c|c|c|c|c|c|c|}
\hline \multirow{3}{*}{$\begin{array}{l}\text { Independent variable } \\
\text { Returnee }\end{array}$} & \multicolumn{3}{|c|}{2011} & \multicolumn{3}{|c|}{2015} & \multicolumn{3}{|c|}{2011 and 2015} \\
\hline & \multicolumn{9}{|c|}{ Employee } \\
\hline & $\begin{array}{c}0.05 \\
(0.53)\end{array}$ & $\begin{array}{c}0.04 \\
(0.52)\end{array}$ & $\begin{array}{c}0.06 \\
(0.68)\end{array}$ & $\begin{array}{c}0.00 \\
(0.04)\end{array}$ & $\begin{array}{c}0.01 \\
(0.04)\end{array}$ & $\begin{array}{c}-0.05 \\
(-0.33)\end{array}$ & $\begin{array}{c}0.02 \\
(0.35)\end{array}$ & $\begin{array}{c}0.02 \\
(0.28)\end{array}$ & $\begin{array}{c}0.00 \\
(0.08)\end{array}$ \\
\hline & \multicolumn{9}{|c|}{ Self-employment } \\
\hline Returnee & $\begin{array}{c}-0.09 * * \\
(-1.96)\end{array}$ & $\begin{array}{c}-0.09 * * \\
(-2.08)\end{array}$ & $\begin{array}{c}-0.11 * * \\
(-2.31)\end{array}$ & $\begin{array}{l}-0.17 * \\
(-1.65)\end{array}$ & $\begin{array}{l}-0.19 * \\
(-1.86) \\
\text { Farmin }\end{array}$ & $\begin{array}{l}-0.18^{*} \\
(-1.79)\end{array}$ & $\begin{array}{c}-0.13 * * \\
(-2.24)\end{array}$ & $\begin{array}{c}-0.14 * * \\
(-2.48)\end{array}$ & $\begin{array}{c}-0.15 * * \\
(-2.56)\end{array}$ \\
\hline Returnee & $\begin{array}{c}0.17 \\
(1.48)\end{array}$ & $\begin{array}{l}0.20^{*} \\
(1.86)\end{array}$ & $\begin{array}{c}0.18 \\
(1.58)\end{array}$ & $\begin{array}{c}0.23 \\
(1.56)\end{array}$ & $\begin{array}{l}0.25^{*} \\
(1.68)\end{array}$ & $\begin{array}{l}0.28 * \\
(1.84)\end{array}$ & $\begin{array}{c}0.20 * * \\
(2.05)\end{array}$ & $\begin{array}{c}0.23 * * \\
(2.43)\end{array}$ & $\begin{array}{c}0.24 * * \\
(2.41)\end{array}$ \\
\hline Individual controls & & $\mathrm{X}$ & $X$ & & $X$ & $X$ & & $X$ & $X$ \\
\hline Household controls & & & $\mathrm{X}$ & & & $\mathrm{X}$ & & & $X$ \\
\hline IV 2SLS & $X$ & $\mathrm{X}$ & $\mathrm{X}$ & $X$ & $\mathrm{X}$ & $X$ & $X$ & $\mathrm{X}$ & $X$ \\
\hline Observations & 1,306 & 1,306 & 1,306 & 1,458 & 1,458 & 1,458 & 2,760 & 2,760 & 2,760 \\
\hline
\end{tabular}

Notes: table shows results from separate regressions. "Returnee" indicates that the individual is a return migrant. Those with education as their main activity are excluded from the analysis in this table. $* * *$ indicates that the coefficient is significant at the $1 \%$ level. $* *$ indicates that the coefficient is significant at the 5\% level. * indicates that the coefficient is significant at the $10 \%$ level. $\mathrm{t}$ statistics are included in parenthesis. In estimations in which we pool both rounds of the survey, we add a time dummy. 
Table 9 - Impact of being a returnee on all economic activities (2015).

\begin{tabular}{|c|c|c|c|}
\hline Independent variable & (1) & (2) & (3) \\
\hline & \multicolumn{3}{|c|}{ Agricultural employee } \\
\hline \multirow[t]{2}{*}{ Returnee } & $\begin{array}{c}0.47 * * * \\
(2.73)\end{array}$ & $\begin{array}{c}0.51 * * * \\
(2.96)\end{array}$ & $\begin{array}{c}0.48 * * * \\
(2.71)\end{array}$ \\
\hline & \multicolumn{3}{|c|}{ Non-agricultural employee } \\
\hline Returnee & $\begin{array}{l}-0.02 \\
(-0.22)\end{array}$ & $\begin{array}{c}-0.03 \\
(-0.32)\end{array}$ & $\begin{array}{l}-0.05 \\
(-0.40)\end{array}$ \\
\hline Returnee & $\begin{array}{c}-0.07 \\
(-0.46)\end{array}$ & $\begin{array}{c}\text {-employn } \\
-0.10 \\
(-0.69) \\
\text { Farming }\end{array}$ & $\begin{array}{c}-0.11 \\
(-0.75)\end{array}$ \\
\hline Returnee & $\begin{array}{l}0.25 * * \\
(2.25)\end{array}$ & $\begin{array}{c}0.27 * * \\
(2.40)\end{array}$ & $\begin{array}{l}0.25 * * \\
(2.12)\end{array}$ \\
\hline $\begin{array}{l}\text { Individual controls } \\
\text { Household controls }\end{array}$ & & $X$ & $\begin{array}{l}\mathrm{X} \\
\mathrm{X}\end{array}$ \\
\hline IV 2SLS & $X$ & $X$ & $X$ \\
\hline Observations & 1,461 & 1,461 & 1,461 \\
\hline
\end{tabular}

Note: table shows results from separate regressions. "Returnee" indicates that the individual is a return migrant. Those with education as their main activity are excluded from the analysis in this table. $* * *$ indicates that the coefficient is significant at the $1 \%$ level. $* *$ indicates that the coefficient is significant at the 5\% level. * indicates that the coefficient is significant at the $10 \%$ level. $t$ statistics are included in parenthesis. In estimations in which we pool both rounds of the survey, we add a time dummy. 
Table 10 - Livestock levels in household by economic activity for stayees

\begin{tabular}{lcc}
\hline Variable & Main activity & All activities \\
\hline Employee & 0.21 & 0.18 \\
Agricultural employee & & 0.15 \\
Non-agricultural employee & & 0.24 \\
Self-employment & 0.28 & 0.25 \\
Farming & 0.23 & 0.22 \\
\hline
\end{tabular}

Note: table only includes stayees. 
Table 11 - Impact of being a returnee on exposure to crime and health shocks (since 2005)

\begin{tabular}{|c|c|c|c|c|c|c|}
\hline \multirow{2}{*}{ Independent variable } & \multicolumn{6}{|c|}{2011} \\
\hline & (1) & $(2)$ & (3) & (4) & $(5)$ & $(6)$ \\
\hline & \multicolumn{3}{|c|}{ Theft livestock } & \multicolumn{3}{|c|}{ Serious illness any member } \\
\hline \multirow{2}{*}{ Returnee household } & 0.01 & -0.08 & -0.11 & 0.04 & $-0.23 * *$ & $-0.26 * *$ \\
\hline & $(0.58)$ & $(-1.24)$ & $(-1.52)$ & $(1.33)$ & $(-1.98)$ & $(-2.07)$ \\
\hline \multirow{3}{*}{ Share returnees } & 0.00 & -0.15 & -0.20 & 0.00 & $-0.00 * *$ & $-0.01 * *$ \\
\hline & $(0.12)$ & $(-1.24)$ & $(-1.51)$ & (1.07) & $(-1.97)$ & $(-2.09)$ \\
\hline & \multicolumn{3}{|c|}{ Theft cash } & \multicolumn{3}{|c|}{ Serious illness adult women } \\
\hline \multirow{2}{*}{ Returnee household } & 0.03 & $-0.12 *$ & $-0.14 *$ & 0.02 & $-0.21 * *$ & $-0.23 * *$ \\
\hline & $(1.47)$ & $(-1.65)$ & $(-1.79)$ & $(0.79)$ & $(-2.31)$ & $(-2.36)$ \\
\hline \multirow{3}{*}{ Share returnees } & 0.02 & $-0.24 *$ & $-0.25^{*}$ & 0.07 & $-0.41 * *$ & $-0.43 * *$ \\
\hline & $(0.62)$ & $(-1.65)$ & $(-1.79)$ & $(0.99)$ & $(-2.26)$ & $(-2.33)$ \\
\hline & \multicolumn{3}{|c|}{ Theft agricultural tools } & \multicolumn{3}{|c|}{ Serious illness adult men } \\
\hline \multirow{2}{*}{ Returnee household } & 0.02 & -0.01 & -0.00 & 0.01 & $-0.16^{* *}$ & $-0.17 * *$ \\
\hline & $(1.17)$ & $(-0.19)$ & $(-0.00)$ & $(0.27)$ & $(-2.37)$ & $(-2.38)$ \\
\hline \multirow{3}{*}{ Share returnees } & 0.00 & -0.01 & -0.00 & 0.00 & $-0.30 * *$ & $-0.31 * *$ \\
\hline & $(0.35)$ & $(-0.19)$ & $(-0.00)$ & $(0.08)$ & $(-2.32)$ & $(-2.34)$ \\
\hline & \multicolumn{3}{|c|}{ Theft other assets } & \multicolumn{3}{|c|}{ Serious illness child } \\
\hline \multirow{2}{*}{ Returnee household } & 0.01 & 0.02 & 0.02 & 0.01 & -0.07 & -0.08 \\
\hline & $(0.77)$ & $(0.51)$ & $(0.31)$ & $(0.61)$ & $(-0.88)$ & $(-1.00)$ \\
\hline \multirow{2}{*}{ Share returnees } & -0.00 & 0.05 & 0.03 & -0.00 & -0.13 & -0.15 \\
\hline & $(-0.22)$ & $(0.51)$ & $(0.31)$ & $(-0.02)$ & $(-0.88)$ & $(-1.01)$ \\
\hline Controls & $X$ & & $X$ & $X$ & & $\mathrm{X}$ \\
\hline IV 2SLS & & $\mathrm{X}$ & $\mathrm{X}$ & & $\mathrm{X}$ & $\mathrm{X}$ \\
\hline Observations & 904 & 904 & 904 & 904 & 904 & 904 \\
\hline
\end{tabular}

Note: $* * *$ indicates that the coefficient is significant at the $1 \%$ level. $* *$ indicates that the coefficient is significant at the 5\% level. * indicates that the coefficient is significant at the $10 \%$ level. $t$ statistics are included in parenthesis. 
Table 12 - Impact of time since return and time abroad on livestock (TLUs).

\begin{tabular}{|c|c|c|c|c|c|c|}
\hline \multirow{2}{*}{ Independent variable } & \multicolumn{2}{|c|}{2011} & \multicolumn{2}{|c|}{2015} & \multicolumn{2}{|c|}{2011 and 2015} \\
\hline & (1) & (2) & (3) & (4) & $(5)$ & $(6)$ \\
\hline Years since return in 2011 & & & & & & \\
\hline Over 10 years & $\begin{array}{c}0.03 \\
(-1.52)\end{array}$ & $\begin{array}{l}-0.34 \\
(-1.10)\end{array}$ & $\begin{array}{l}-0.04 \\
(-1.55)\end{array}$ & $\begin{array}{c}-0.34 \\
(-1.03)\end{array}$ & $\begin{array}{c}-0.04 * * \\
(-2.15)\end{array}$ & $\begin{array}{l}-0.34 \\
(-1.49)\end{array}$ \\
\hline Observations & 847 & 847 & 847 & 847 & 847 & 847 \\
\hline 0 to 10 years & $\begin{array}{c}-0.04 \\
(-1.42)\end{array}$ & $\begin{array}{l}-0.09 \\
(-0.77)\end{array}$ & $\begin{array}{c}-0.07 * * \\
(-2.23)\end{array}$ & $\begin{array}{l}-0.20^{*} \\
(-1.94)\end{array}$ & $\begin{array}{c}-0.05 * * * \\
(-2.63)\end{array}$ & $\begin{array}{l}-0.15^{*} \\
(-1.84)\end{array}$ \\
\hline $\begin{array}{l}\text { Observations } \\
\text { Time spent abroad }\end{array}$ & 803 & 803 & 803 & 803 & 803 & 803 \\
\hline Over 10 years & $\begin{array}{c}-0.06 * * \\
(-2.23)\end{array}$ & $\begin{array}{c}-0.16 \\
(-0.98)\end{array}$ & $\begin{array}{c}-0.05 \\
(-0.98)\end{array}$ & $\begin{array}{c}-0.26 \\
(-1.58)\end{array}$ & $\begin{array}{c}-0.06 * * \\
(-2.00)\end{array}$ & $\begin{array}{l}-0.21 * \\
(-1.77)\end{array}$ \\
\hline Observations & 804 & 804 & 804 & 804 & 804 & 804 \\
\hline 0 to 10 years & $\begin{array}{c}-0.01 \\
(-0.61)\end{array}$ & $\begin{array}{l}-0.14 \\
(-0.74)\end{array}$ & $\begin{array}{l}-0.04^{*} \\
(-1.65)\end{array}$ & $\begin{array}{c}-0.30 \\
(-1.62)\end{array}$ & $\begin{array}{l}-0.03^{*} \\
(-1.65)\end{array}$ & $\begin{array}{c}-0.22 \\
(-1.64)\end{array}$ \\
\hline Observation & 878 & 878 & 878 & 878 & 878 & 878 \\
\hline $\begin{array}{l}\text { Controls } \\
\text { IV 2SLS }\end{array}$ & $X$ & $\begin{array}{l}X \\
X\end{array}$ & $\mathrm{X}$ & $\begin{array}{l}X \\
X\end{array}$ & $\mathrm{X}$ & $\begin{array}{l}X \\
X\end{array}$ \\
\hline
\end{tabular}

Note: table shows results from separate regressions. Returnee households not included in the specific definition of the estimation (e.g. those who spent over ten years abroad when the dummy is for those who spent ten years or less abroad) are dropped from the sample and not included in the comparison group. Note that the same household could be in both categories (e.g. one member spend over ten years abroad and another spent less than ten years abroad). *** indicates that the coefficient is significant at the $1 \%$ level. $* *$ indicates that the coefficient is significant at the $5 \%$ level. * indicates that the coefficient is significant at the $10 \%$ level. t statistics are included in parenthesis. In estimations in which we pool both rounds of the survey, we add a time dummy. 
Table 13 - Average treatment effect on the treated: Livestock outcomes

\begin{tabular}{lccccc}
\hline Treatment & Treated & Control & Difference & Standard & Bootstrapped \\
\hline & \multicolumn{5}{c}{ Nearest Neighbor Estimator } \\
Returnee household & 0.09 & 0.22 & -0.13 & $-2.83^{* * *}$ & $-2.01^{* * *}$ \\
& 0.15 & 0.19 & -0.05 & -1.09 & -1.00 \\
\hline
\end{tabular}

Note: $* * *$ indicates that the coefficient is significant at the $1 \%$ level. $* *$ indicates that the coefficient is significant at the $5 \%$ level. 
Figure 1 - Burundi and vicinity

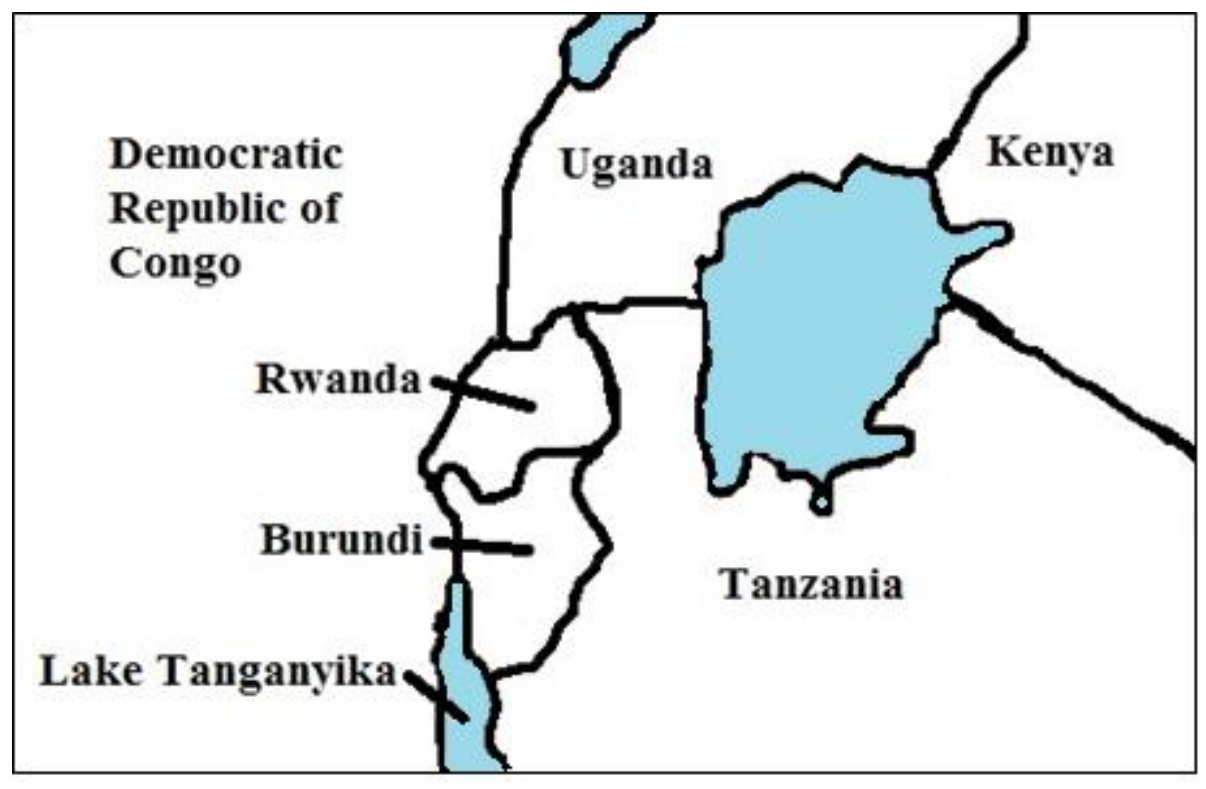


Figure 2 - Number of refugees in Tanzania per province of origin [brackets] and as a share of the province's 1990 population (parenthesis).

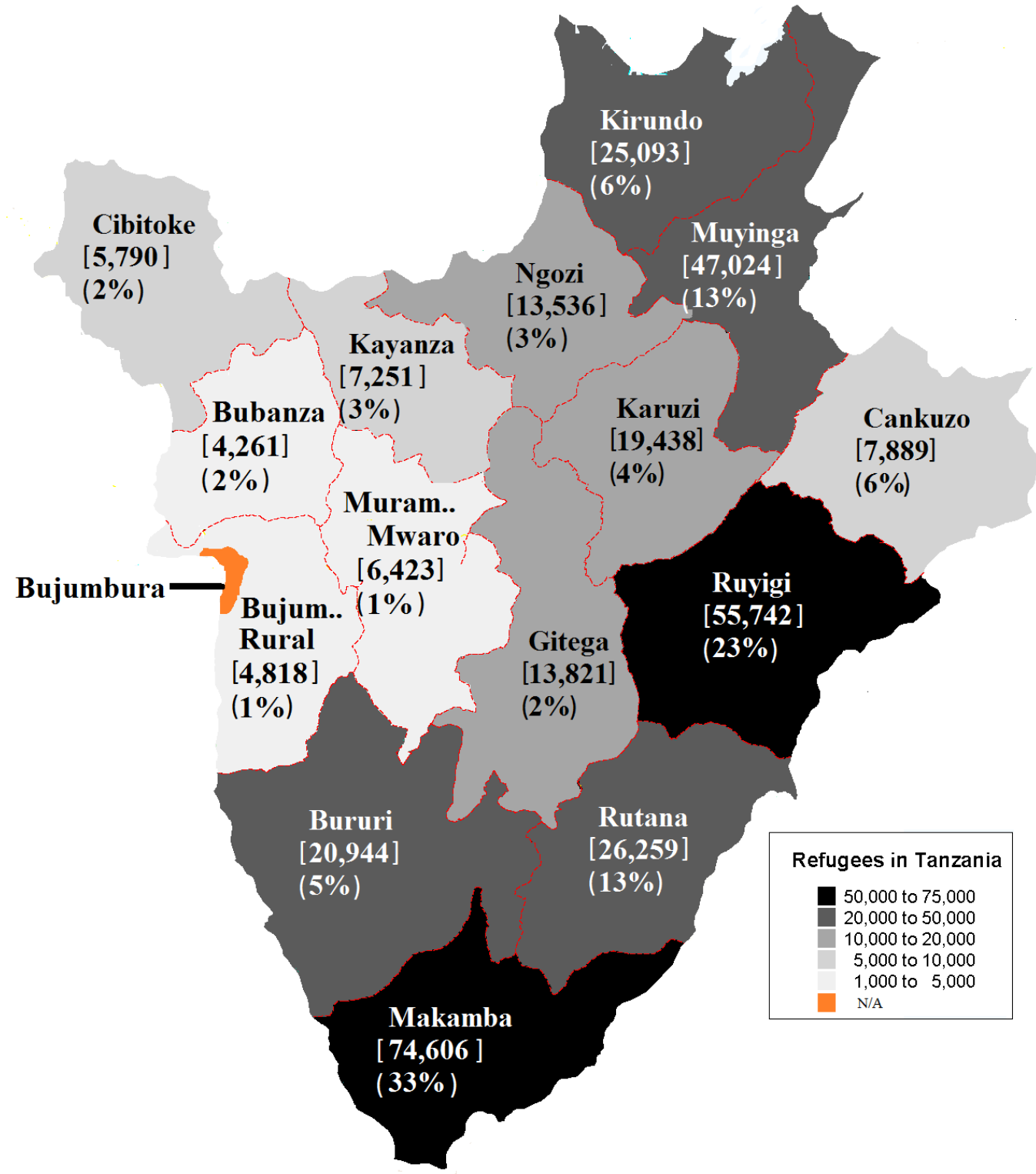

Note: data reflects the situation in mid-2000. Source of information on refugees in Tanzania is UNHCR. Data on share of the province population constructed with information from the 1990 Census. Note that Muramvya and Mwaro were one province during the period of interest. 
Figure 3 - Returnees from Tanzania to Burundi.

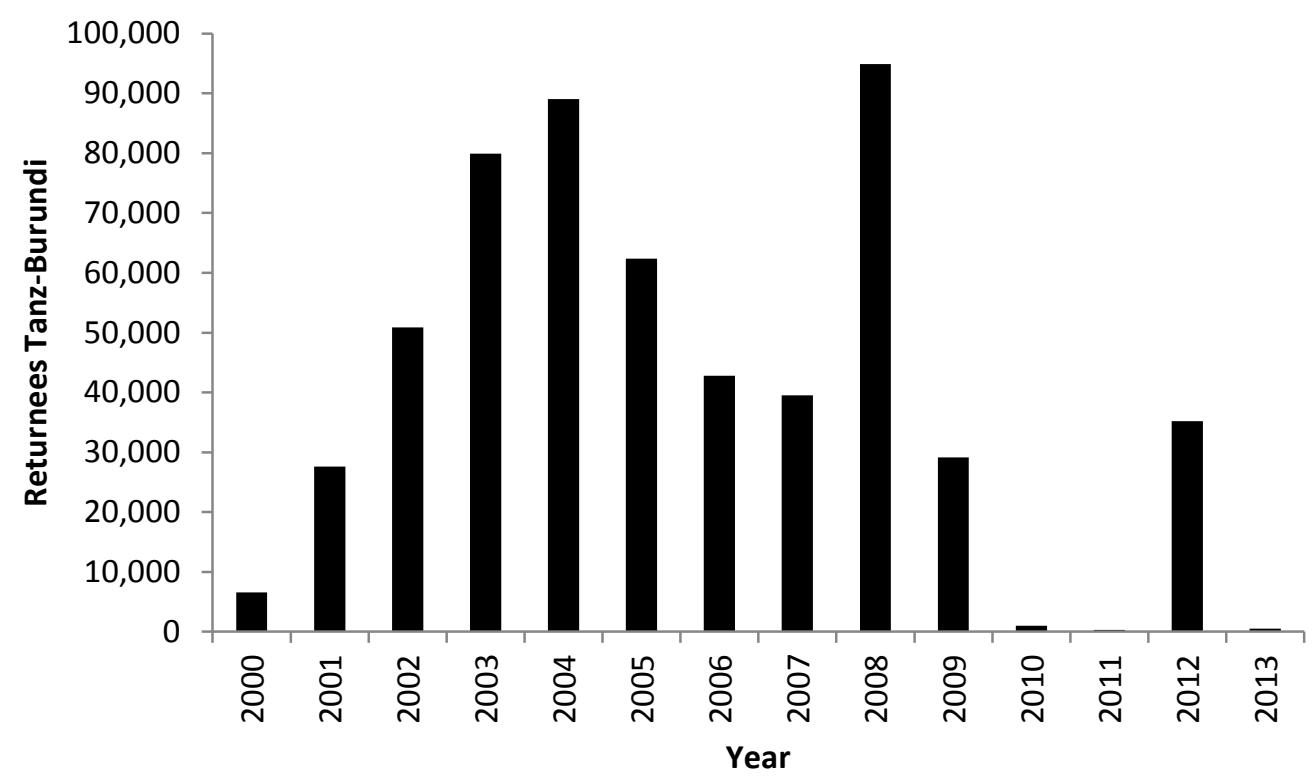

Note: source of data is UNHCR. 
Figure 4 - Location of the communities surveyed

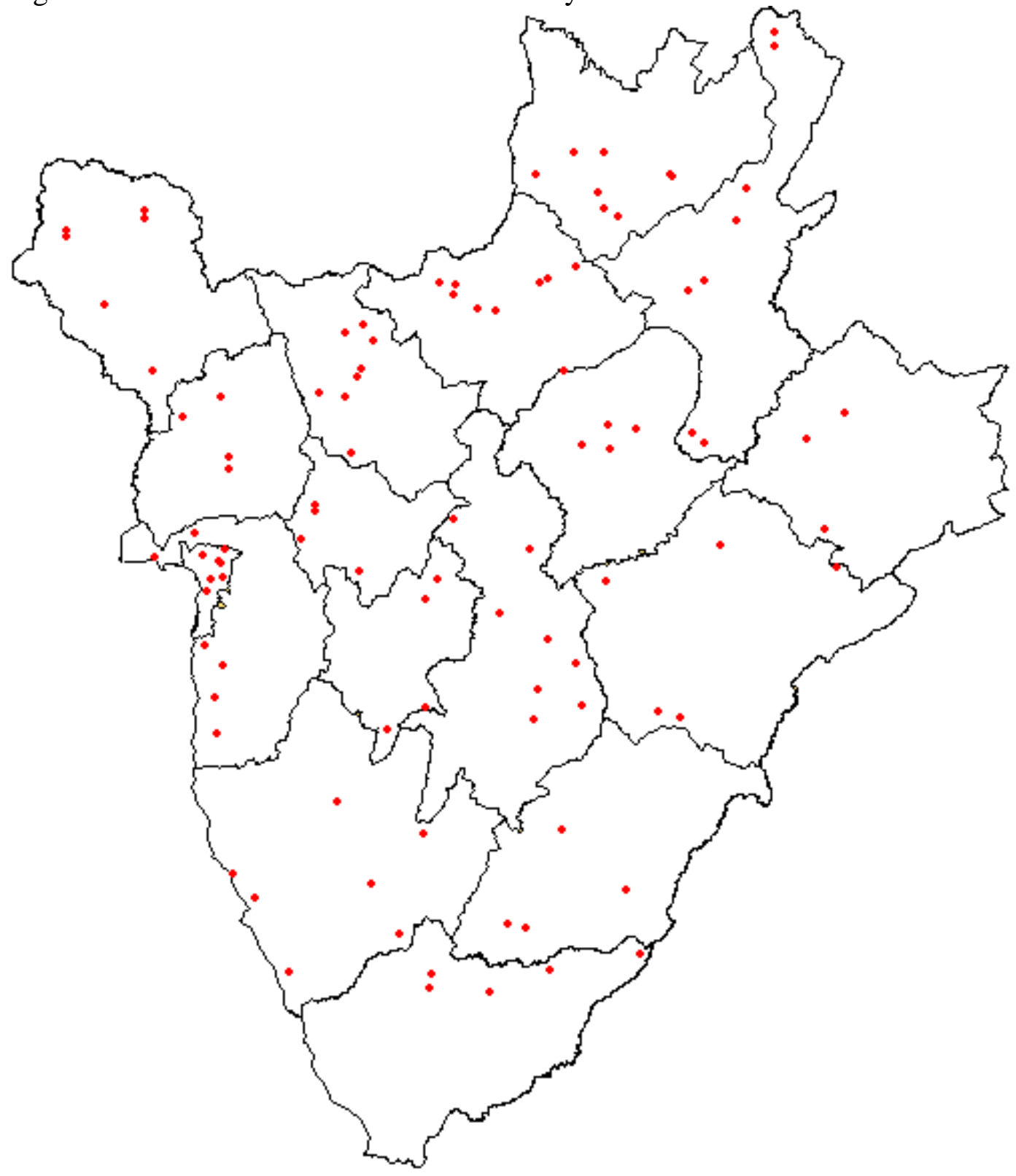

Note: The data collection for this study took place between January and March of 2011 and 2015 in all 17 provinces of Burundi. The communities sampled were selected according to the demographic weight of these provinces in the 2008 Burundi Census. The Figure above shows the distribution of the communities across Burundi. 
Figure 5 - Year of return of returnees in the sample

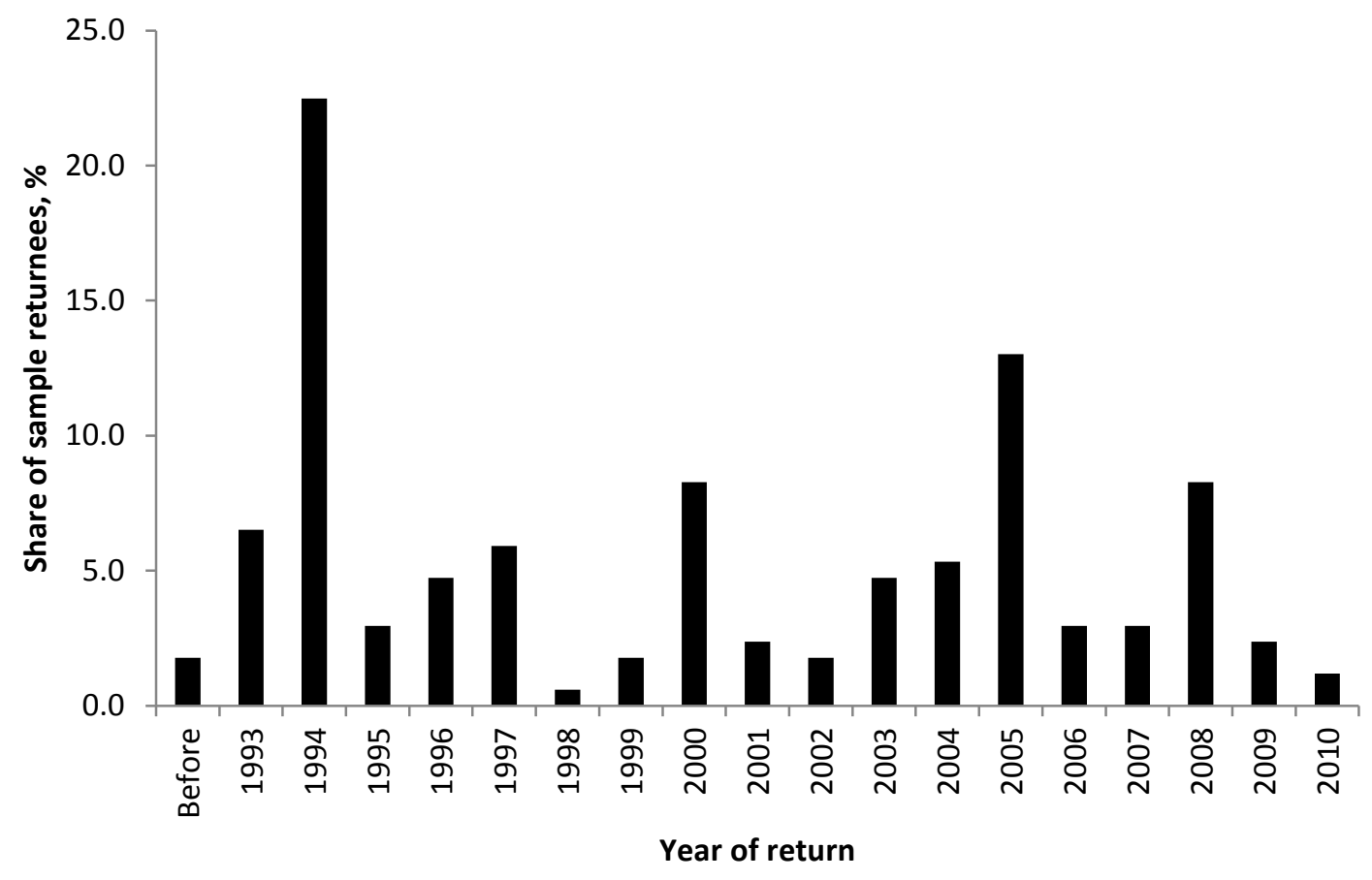

